\title{
Symmetrical and Asymmetrical H-Bridge Multilevel Inverter for DTC Induction Motor Drive Automotive Applications
}

\author{
F. Khoucha ${ }^{1,2}$, S.M. Lagoun ${ }^{2}$, A. Kheloui ${ }^{2}$ and M.E.H. Benbouzid ${ }^{1}$ \\ ${ }^{1}$ University of Brest, EA 4325 LBMS \\ IUT of Brest - Rue de Kergoat - CS 93837, 29238 Brest Cedex 03, France \\ E-mail: m.benbouzid@ieee.org \\ ${ }^{2}$ Electrical Engineering Department, Polytechnic Military Academy, 16111 Algiers, Algeria.
}

\begin{abstract}
Several works have been reported in the literature on multilevel inverters topologies, control techniques and applications. However, there are few works that actually discuss or evaluate the performance of induction motor drives associated to three-phase multilevel inverter. This paper presents then a comparison study for a cascaded H-bridge multilevel DTC induction motor drive. In this case, symmetrical and asymmetrical arrangements of five and seven level $\mathrm{H}$-bridge inverters are compared in order to find an optimum arrangement with lower switching losses and optimized output voltage quality. The carried out experiments shows that an asymmetrical configuration provides nearly sinusoidal voltages with very low distortion, using less switching devices. Due to the small dv/dt's, torque ripple is greatly reduced. In addition, it generates a high switching frequency output voltage with less switching losses, since only the small power cells of the inverter operate at high switching rate. Therefore a high performance and also efficient torque and flux controller is obtained, enabling a DTC solution for multilevel inverter powered induction motor drives.
\end{abstract}

Index Terms - Induction motor, Direct Torque Control (DTC), multilevel inverters.

\section{INTRODUCTION}

Multilevel voltage-source inverters are intensively studied for high-power applications [1-2], and standard drives for medium-voltage industrial applications have become available [3-4]. Solutions with a higher number of output voltage levels have the capability to synthesize waveforms with a better harmonic spectrum and to limit the motorwinding insulation stress. However, their increasing number of devices tends to reduce the overall reliability and efficiency of the power converter. On the other hand, solutions with a low number of levels either need a rather large and expensive $L C$ output filter to limit the motorwinding insulation stress or can only be used with motors that do withstand such stress. The various stage voltages have been chosen after considering the real power contribution of the highest voltage stage. The maximum power supplied by highest voltage stage is maintained below the load power.

Many studies have been conducted towards improving multilevel inverter. Some studies deal with innovative topologies such as hybrid multilevel inverter to optimize the components utilization and the asymmetrical multilevel inverter to improve the output voltage resolution [5]. Other studies focused on developing advanced control strategies or upgrading the voltage source inverter strategies for implementation in multilevel inverter [6-7].

In symmetrical multilevel inverter, all $\mathrm{H}$-bridge cells are fed by equal voltages and hence all the arm cells produce similar output voltage steps. However if all the cells are not fed by equal voltages, the inverter becomes an asymmetrical one. In this inverter the arm cells have different effect on the output voltage. Other topologies are possible such as the neutral point clamped fed by unequal capacitors.

Asymmetrical multilevel inverter has been recently investigated [8-9]. In all these studies H-bridge topology has been considered and a variety of selection of cascaded cell numbers and DC sources ratios have been adopted. While the four cells symmetrical multilevel inverter has five levels, a 7and 9-level inverter has been constructed with two cell asymmetrical multilevel inverter [8]. The suggested PWM modulation strategy that maintains the high voltage stage to operate at low frequency limits the source voltage selection.

One of the methods that have been used by a major multilevel-level inverter manufacturer is DTC, which is recognized today as a high-performance control strategy for AC drives [10-13]. Several authors have addressed the problem of improving the behavior of DTC AC motors, especially by reducing the torque ripple. Different approaches have been proposed [14]: improving the look-up table; varying the hysteresis bandwidth of the torque controller, using flux, torque and speed observers. Although these approaches are well suitable for the classical 2-levels inverter, their extension to a greater number of levels is not easy.

\section{CASCADED H-BRIDGES STRUCTURE AND OPERATION}

The cascaded H-bridge inverter consists of power conversion cells, each supplied by an isolated DC source on the DC side, which can be obtained from batteries, fuel cells, or ultracapacitors [15-16], and series-connected on the AC side. The advantage of this topology is that the modulation, control and protection requirements of each bridge are modular. It should be pointed out that, unlike the diodeclamped and flying-capacitor topologies, isolated DC sources are required for each cell in each phase. Figure 1 shows a three-phase topology of a cascade inverter with isolated DC voltage sources. An output phase voltage waveform is obtained by summing the bridges output voltages 
$v_{o}(t)=v_{o, 1}(t)+v_{o, 2}(t)+\cdots+v_{o, N}(t)$

where $N$ is the number of cascaded bridges.

The inverter output voltage $v_{o}(t)$ may be determined from the individual cells switching states.

$v_{o}(t)=\sum_{j=1}^{N}\left(\mu_{j}-1\right) V_{d c, j} \quad \mu_{j}=0,1, \ldots$

If all DC voltage sources in Fig. 1 are equal to $V_{d c}$ the inverter is then known as a symmetric multilevel one. The effective number of output voltage levels $n$ in symmetric multilevel inverter is related to the cells number by

$n=1+2 N$

For example, Fig. 2 illustrated typical waveforms of Fig. 1 multilevel inverter with two DC sources (5-levels output). The maximum output voltage $V_{\mathrm{o} \text { Max }}$ is then

$V_{o, M A X}=N V_{d c}$

To provide a large number of output levels without increasing the number of inverters, asymmetric multilevel inverters can be used.

In [17-18], it is proposed to chose the DC voltages sources according to a geometric progression with a factor of 2 or 3 . For $N$ of such cascade inverters, one can achieve the following distinct voltage levels.

$\begin{cases}n=2^{N+1}-1 & \text { if } V_{d c, j}=2^{j-1} V_{d c}, j=1,2, \ldots, N \\ n=3^{N} & \text { if } V_{d c, j}=3^{j-1} V_{d c}, j=1,2, \ldots, N\end{cases}$

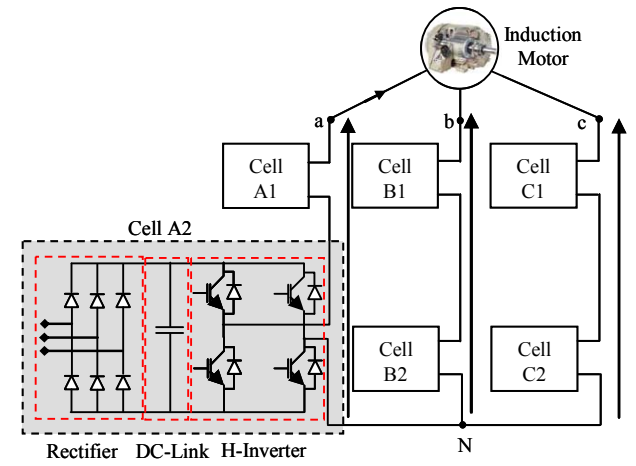

Fig. 1. Structure of 2-cells cascaded multilevel inverter.
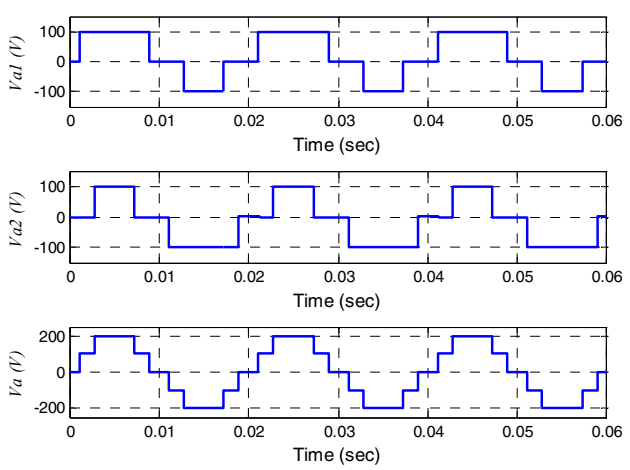

Fig. 2. Symmetric multilevel inverter with 5-levels output voltage synthesis.
For example, Fig. 3 illustrated typical waveforms of Fig. 1 multilevel inverter with two DC sources $\left(V_{d c}\right.$ and $\left.2 V_{d c}\right)$ (7levels output).

The maximum output voltage of these $N$ cascaded multilevel inverters is

$V_{o, M A X}=\sum_{j=1}^{N} V_{d c, j}$

Equation (6) can be rewritten as

$\begin{cases}V_{o, M A X}=\left(2^{N}-1\right) V_{d c} & \text { if } V_{d c, j}=2^{j-1} V_{d c}, j=1,2, \ldots, N \\ V_{o, M A X}=\left(\frac{3^{N}-1}{2}\right) V_{d c} & \text { if } V_{d c, j}=3^{j-1} V_{d c}, j=1,2, \ldots, N\end{cases}$

Comparing (3) to (7), it can be seen that asymmetrical multilevel inverters can generate more voltage levels and higher maximum output voltage with the same number of bridges. Table 1 summarizes the number of levels, switches, DC sources and maximum available output voltages for classical cascaded multilevel inverters.

\section{INDUCTION MOTOR DIRECT TORQUE CONTROL}

DTC is an alternative method to flux oriented control [12]. However, in the standard version, important torque ripple is obtained even at high sampling frequencies. Moreover, the inverter switching frequency is inherently variable and very dependent on torque and shaft speed. This produces torque harmonics with variable frequencies and an acoustic noise with disturbance intensities very dependent on these mechanical variables and particularly grating at low speed.
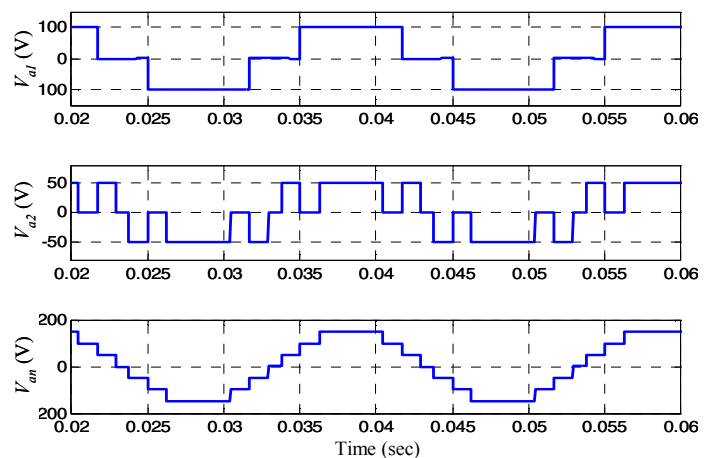

Fig. 3. Asymmetric multilevel inverter with 7-levels output voltage synthesis.

Table 1. Comparison of multilevel inverters.

\begin{tabular}{|c|c|c|c|}
\hline & \multirow{2}{*}{$\begin{array}{c}\text { Symmetrical } \\
\text { inverter }\end{array}$} & \multicolumn{2}{|c|}{ Asymmetrical inverter } \\
\cline { 3 - 4 } & $2 N+1$ & $2^{N+1}-1$ & $3^{N}$ \\
\hline$N$ & $N$ & $N$ & $N$ \\
DC sources number & $4 N$ & $4 N$ & $4 N$ \\
Switches number & $N$ & $2^{N}-1$ & $\left(3^{N}-1\right) / 2$ \\
\hline
\end{tabular}


The additional degrees of freedom (space vectors, phase configurations, etc.) provided by the multilevel inverter should therefore be exploited by the control strategy in order to reduce these drawbacks [6].

\section{A. Nomenclature}

$v_{s} \quad=$ Stator voltage vector;

$\phi_{s}\left(\phi_{r}\right)=$ Stator (rotor) flux vector;

$T_{e} \quad=$ Electromagnetic torque;

$R_{s} \quad=$ Stator resistance;

$L_{s}\left(L_{r}\right)=$ Stator (rotor) inductance;

$L_{m} \quad=$ Magnetizing inductance;

$\sigma \quad=$ Total leakage coefficient, $\sigma=1-L_{m}{ }^{2} / L_{s} L_{r} ;$

$\theta_{s r}=$ Angle between stator and rotor flux vectors;

$p \quad=$ Pole pair number.

\section{B. Torque and Flux Estimation}

The stator flux vector an induction motor is related to the stator voltage and current vectors by:

$$
\frac{d \phi_{s}(t)}{d t}=v_{s}(t)-R_{s} i_{s}(t)
$$

Maintaining $v_{s}$ constant over a sample time interval and neglecting the stator resistance, the integration of (10) yields

$$
\Delta \phi_{s}(t)=\phi_{s}(t)-\phi_{s}(t-\Delta t)=\int_{t-\Delta t}^{t} v_{s} \Delta t
$$

Equation (9) reveals that the stator flux vector is directly affected by variations on the stator voltage vector. On the contrary, the influence of $v_{s}$ over the rotor flux is filtered by the rotor and stator leakage inductance [19], and is, therefore, not relevant over a short-time horizon. Since the stator flux can be changed quickly while the rotor flux rotates slower, the angle between both vectors $\theta_{s r}$ can be controlled directly by $v_{s}$. The exact relationship between stator and rotor flux shows that keeping the amplitude of $\phi_{s}$ constant will produce a constant flux $\phi_{r}[20]$.

Since the electromagnetic torque developed by an induction motor can be expressed by [21]

$$
T_{e}=\frac{3}{2} p \frac{L_{m}}{\sigma L_{s} L_{r}} \phi_{s} \phi_{r} \sin \theta_{s r}
$$

It follows that change in $\theta_{s r}$ due to the action of $v_{s}$ allows for direct and fast change in the developed torque. DTC uses this principle to achieve the induction motor desired torque response, by applying the appropriate stator voltage vector to correct the flux trajectory.

\section{Voltage Vector Selection}

Figure 4 illustrates one of the 127 voltage vectors generated by the inverter at instant $t=k$, denoted by $v_{s}^{k}$ (central dot). The next voltage vector to be applied to the load $v_{s}{ }^{k+1}$, can be expressed by

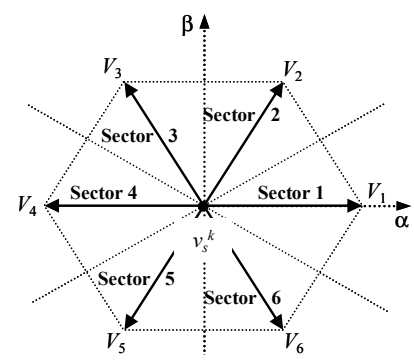

Fig. 4. Possible voltage changes $\Delta v_{s}^{k}$ that can be applied from certain $v_{s}^{k}$.

$v_{s}^{k+1}=v_{s}^{k}+\Delta v_{s}^{k}$

where $\Delta v_{s}^{k}=\left\{v_{i} \mid i=1, \ldots, 6\right\}$. Each vector $v_{i}$ corresponds to one corner of the elemental hexagon illustrated in gray and by the dashed line in Fig. 7. The task is to determine which $v_{s}{ }^{k+1}$ will correct the torque and flux responses, knowing the actual voltage vector $v_{s}^{k}$, the torque and flux errors $e_{\phi}{ }^{k}$ and $e_{T}^{k}$ and the stator flux vector position (sector determined by angle $\theta_{s}$ ). Note that the next voltage vector $v_{s}^{k+1}$ applied to the load will always be one of the six closest vectors to the previous $v_{s}^{k}$, this will soften the actuation effort and reduce high dynamics in torque response due to possible large changes in the reference.

Using (10) and (11), and analyzing, for example, sector (2) illustrated in Fig. 5; the application of $v_{1}$ increases the stator flux amplitude but reduces $\theta_{s r}$ leading to a torque reduction. Conversely, $v_{4}$ reduces the flux magnitude, while it increases $\theta_{s r}$ and thus the torque. If $v_{3}$ is applied to the load, both torque and flux increase, and it is clear that $v_{6}$ produces the inverse effect. Table 2 summarizes vector selections according to the above criterion, for the different sectors and comparators output (desired $\phi_{s}$ and $T_{e}$ corrections).

To implement the DTC of the induction motor fed by an hybrid H-bridge multilevel inverter, one should determine at each sampling period the logic state of the inverter switches as a function of instantaneous values of torque and flux for the selection of the space vector, in the $\alpha-\beta$ frame.

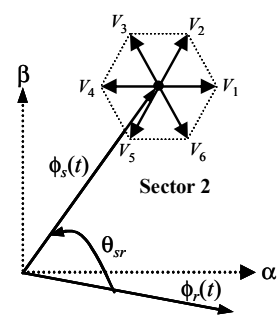

Fig. 5. Voltage selection $\Delta v_{s}^{k}$ in sector 2 .

Table 2. Voltage vector selection lookup table.

\begin{tabular}{|c|c|c|c|c|}
\hline \multirow{2}{*}{ Sector } & \multicolumn{4}{|c|}{$\operatorname{sign}\left(e_{\phi}{ }^{k}, e_{T}{ }^{k}\right)$} \\
\cline { 2 - 5 } & $(+,+)$ & $(+,-)$ & $(-,+)$ & $(-,-)$ \\
\hline 1 & $V_{2}$ & $V_{6}$ & $V_{3}$ & $\mathrm{~V}_{5}$ \\
\hline 2 & $V_{3}$ & $V_{1}$ & $V_{4}$ & $V_{6}$ \\
\hline 3 & $V_{4}$ & $V_{2}$ & $V_{5}$ & $V_{1}$ \\
\hline 4 & $V_{5}$ & $V_{3}$ & $V_{6}$ & $V_{2}$ \\
\hline 5 & $V_{6}$ & $V_{4}$ & $V_{1}$ & $V_{3}$ \\
\hline 6 & $V_{1}$ & $V_{5}$ & $V_{2}$ & $V_{4}$ \\
\hline
\end{tabular}


Once the space is chosen, the sequence of phase levels can be selected. To ensure this task, one should detect the position of the space vector in $\alpha-\beta$ frame $\left(Q^{k}\right.$ at sampling time $\left.t^{k}\right)$. The proposed algorithm must then select the next position $Q^{k+1}$ to be achieved before next sampling instant $t^{k+1}$ (Fig. 6) in order to reduce voltage steps magnitude. This task allows the commutation number reduction in the same phase order to minimize losses and consequently the torque ripple. Finally, the configuration of each phase will be selected and must be able to generate the phase levels.

\section{SIMULATION AND EXPERIMENTAL RESULTS}

For the validation of the above discussed control approach, simulations and experiments have been carried out. Figures 7 to 9 and 10 to 12 show simulation results for 5levels cascaded and 7-levels H-bridge inverter, respectively.

For further verification, a three-phase DSP (TMS320LF2407A) controlled 5- and 7-levels cascaded Hbridge multilevel DTC induction motor drive system prototype was built and tested (Fig. 13). The induction motor was rated at $1-\mathrm{kW} / 380 \mathrm{~V} / 5.2 \mathrm{~A} / 1420 \mathrm{rpm}$. The control cycle is $120 \mu \mathrm{s}$. It should be noted, as illustrated by Fig. 13a, that the experimental setup was built to slightly emulate an automotive application (electric vehicle).

Figures 14 to 16 and 17 to 19 illustrate experimental results for 5-levels cascaded and 7-levels H-bridge inverter, respectively built-up in the laboratory (Fig. 13).

The output voltages form with 7-levels stepped multilevel waveform can be clearly appreciated; the motor currents complete the overview of the performance of the drive. They appear completely sinusoidal, since the low pass nature of the load has filtered the high frequency content of the applied voltage. The stator flux with constant amplitude imposed by the flux controller confirms the good dynamic performance of the drive. The most important results are that torque ripple has been almost eliminated in comparison to 5-levels classic DTC.

\section{CONCLUSIONS}

This paper has presented a comparison of two cascaded $\mathrm{H}-$ bridge multilevel topologies feeding a DTC induction motor. Using the asymmetrical cascade multilevel inverter, which has reduced the number of DC voltage sources and switches, provides more flexibility to designers and can generate more voltage levels.

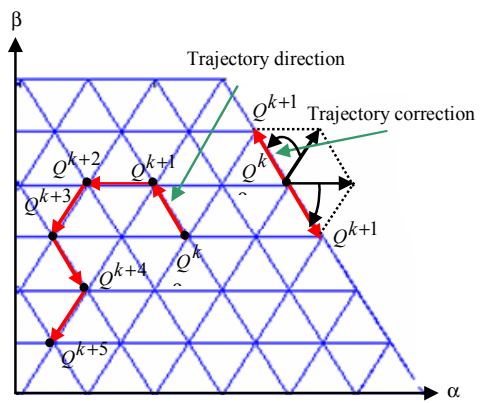

Fig. 6. Optimal space vector tracking and trajectory correction in the stationary $\alpha-\beta$ frame.

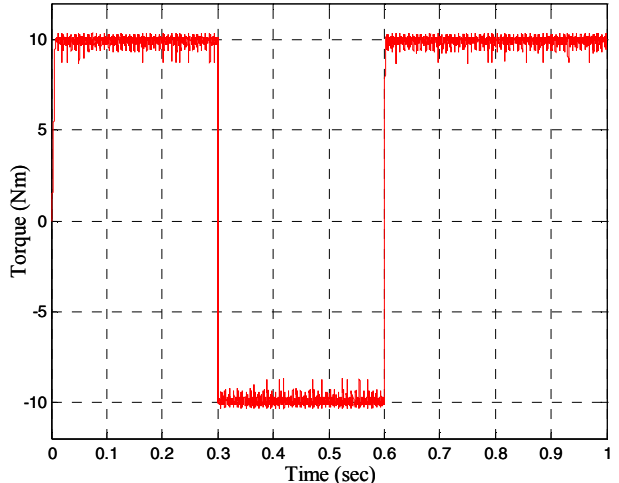

Fig. 7. 5-levels cascaded H-bridge inverter estimated torque waveform.

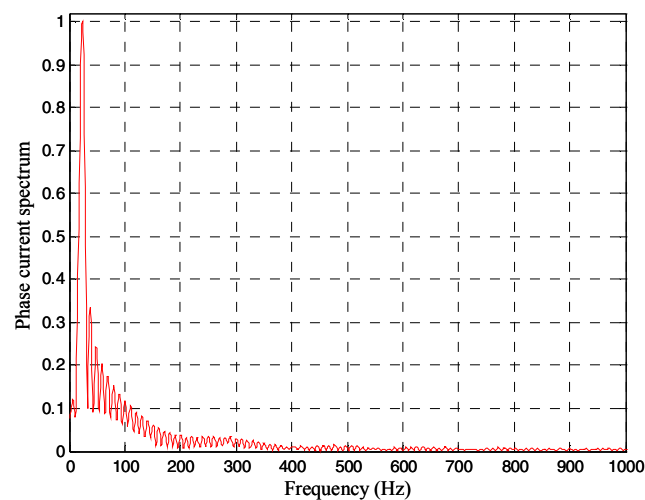

Fig. 8. 5-levels cascaded H-bridge inverter phase current FFT analysis.

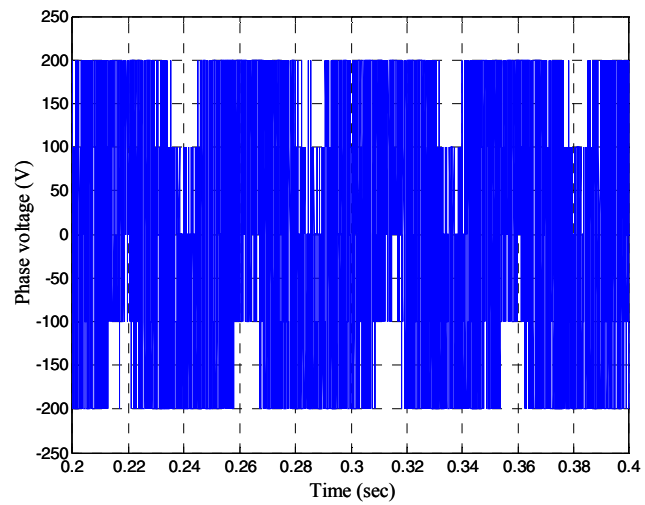

Fig. 9. 5-levels cascaded H-bridge inverter phase voltage waveform.

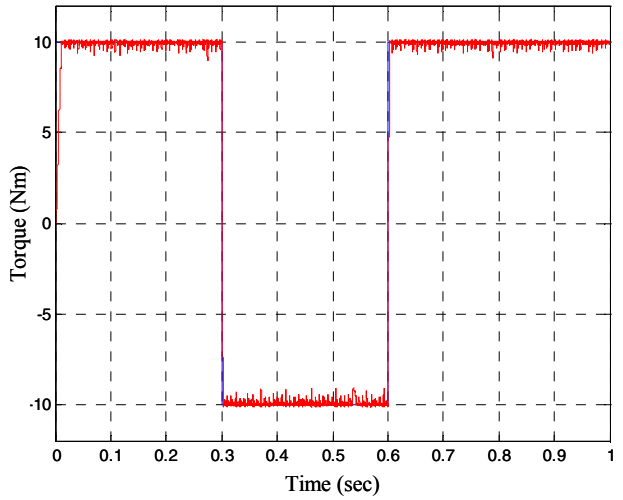

Fig. 10. 7-levels cascaded H-bridge inverter estimated torque waveform. 


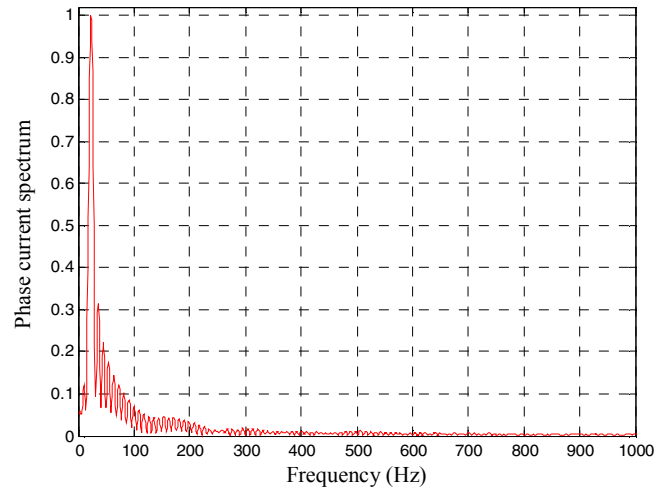

Fig. 11. 7-levels cascaded H-bridge inverter phase current FFT analysis.

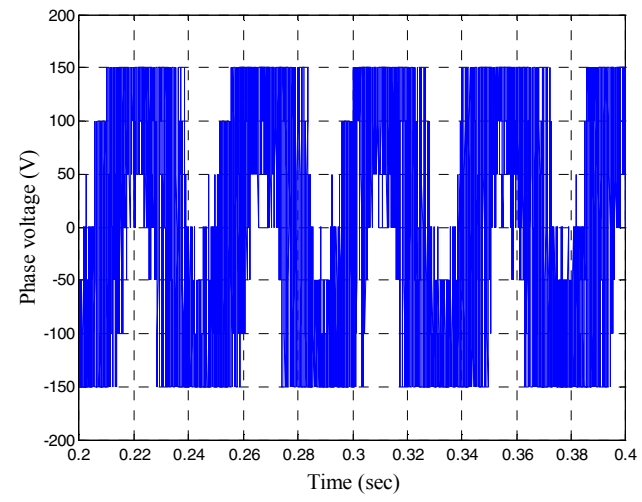

Fig. 12. 7-levels cascaded H-bridge inverter phase voltage waveform.

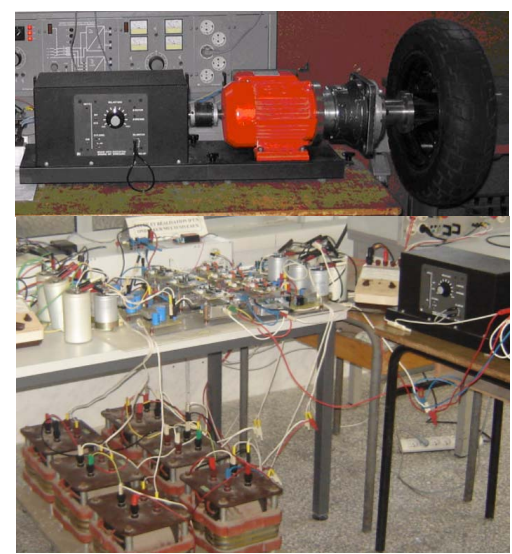

(a)

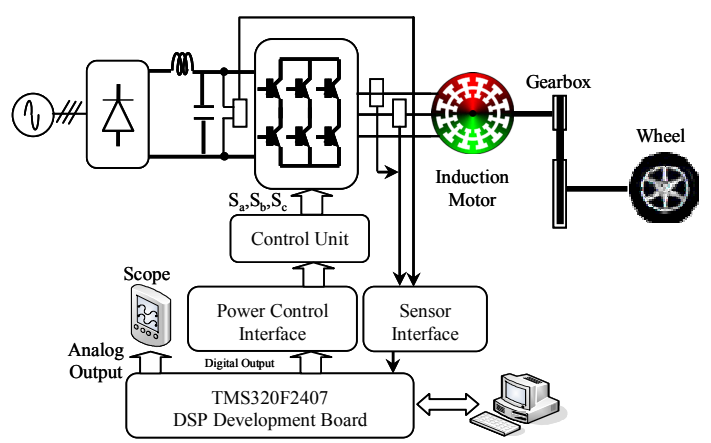

(b)

Fig. 13. The experimental setup.

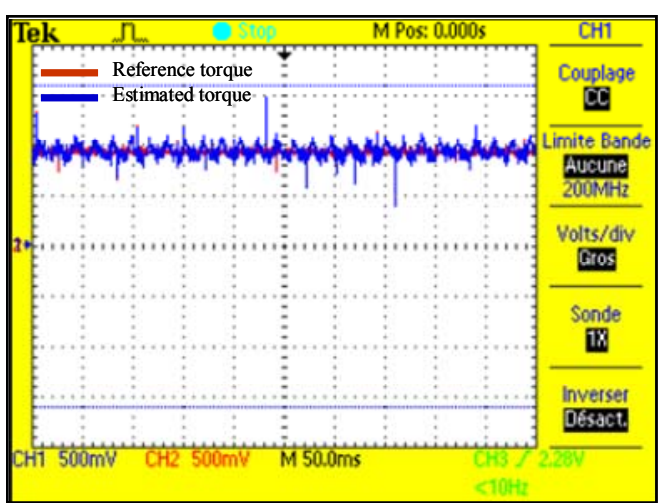

Fig. 14. Torque waveforms for a 5-levels cascaded H-bridge.

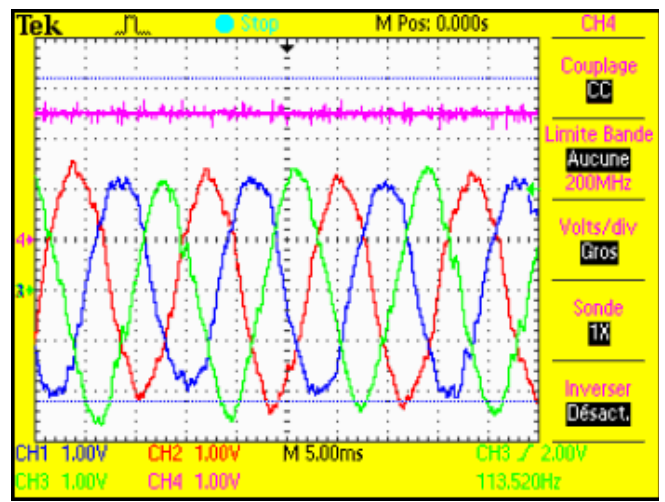

Fig. 15. 5-levels cascaded H-bridge inverter output current waveforms.

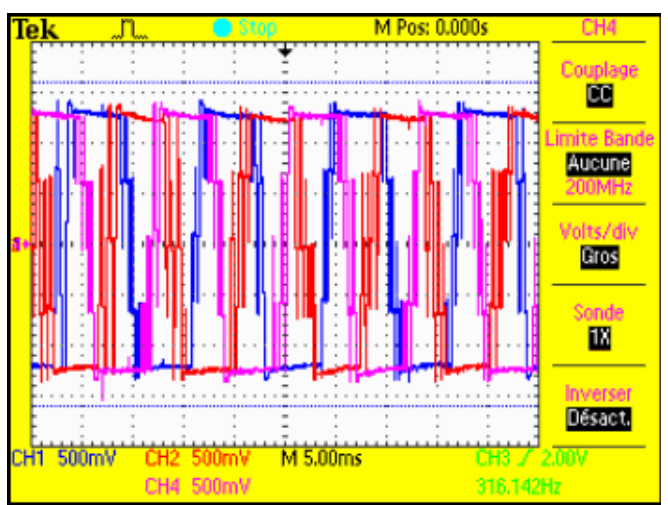

Fig. 16. 5-levels multilevel inverter output voltages during DTC.

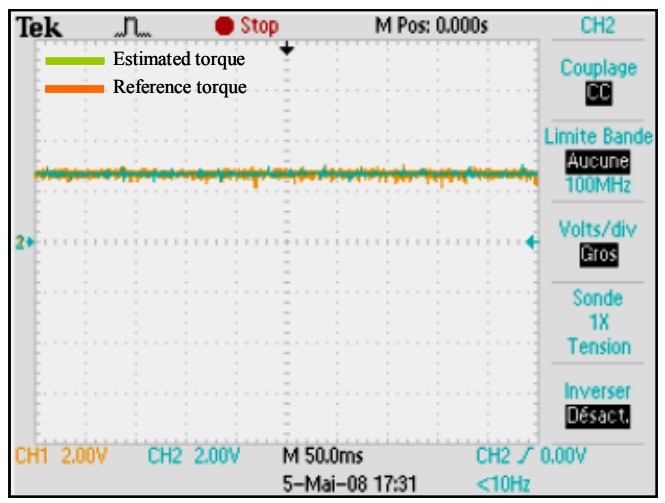

Fig. 17. Torque waveforms for 7-levels cascaded H-bridge. 


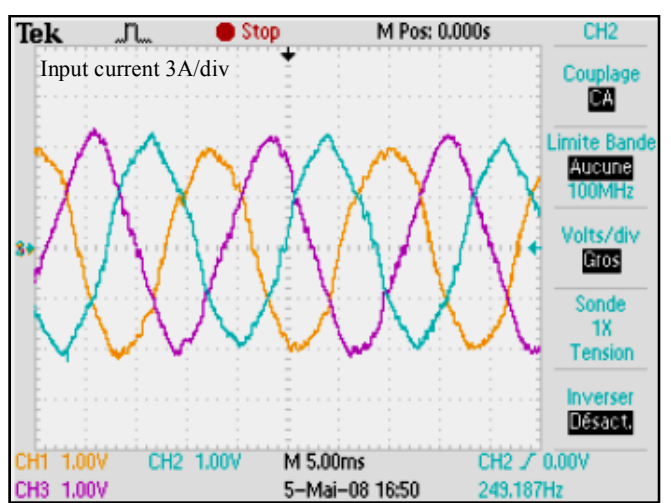

Fig. 18. 7-levels cascaded H-bridge inverter output current waveforms.

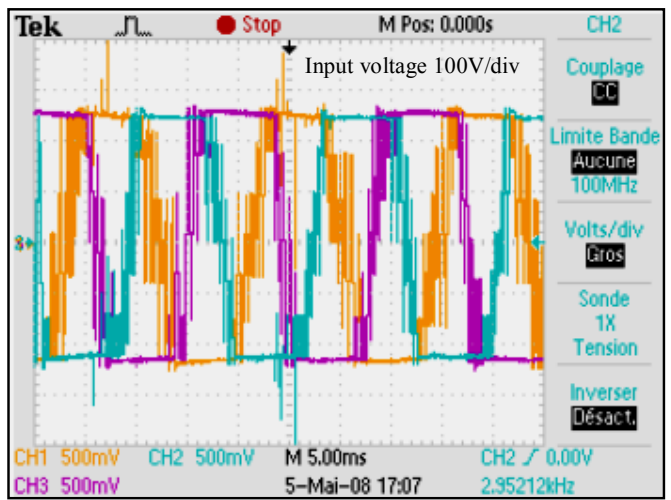

Fig. 19. 7-levels multilevel inverter output voltages during DTC.

This association results in the reduction of the number of switches, losses and coast of the inverter. Based on the DTC the most important achieved results are significant reduction in the torque ripple, sinusoidal output voltages and currents, and a high-performance torque and flux regulation. The asymmetrical multilevel inverter enables a DTC solution for high-power motor drives, not only due to the higher voltage capability provided by multilevel inverters, but mainly due to the reduced switching losses and the improved output voltage quality, which provides sinusoidal current without output filter.

\section{REFERENCES}

[1] L.G. Franquelo et al., "The age of multilevel converters arrives, IEEE Industrial Electronics Magazine," vol. 2, n², pp. 28-39, June 2008.

[2] J. Rodriguez et al., "Multilevel inverters: A survey of topologies, controls and applications," IEEE Trans. Industrial Electronics, vol. 49, n4, pp. 724-738, August 2002.
[3] M. Escalante et al., "Flying capacitor multilevel inverters and DTC motor drive applications," IEEE Trans. Industrial Electronics, vol. 49 , $\mathrm{n}^{\circ} 4$, pp. 805-815, August 2002.

[4] T. Ishida et al., "Fundamental characteristics of five-level double converters with adjustable DC voltages for induction motor drives," IEEE Trans. Industrial Electronics, vol. 49, n²4, pp. 775-782, August 2002.

[5] Y.S. Lai et al., "Topology for hybrid multilevel inverter, IEE Proc. Electric Power Applications," vol. 149, n6, pp. 449-458, November 2002.

[6] F. Khoucha et al., "Hybrid cascaded H-bridge multilevel inverter motor drive DTC control for electric vehicles," in Proceedings of the ICEM'08, Vilamoura (Portugal), September 2008

[7] C. Rech et al., "Impact of hybrid multilevel modulation strategies on input and output harmonic performance," IEEE Trans. Power Electronics, vol. 22, n³, pp. 967-977, May 2007.

[8] M. Veenstra et al., "Control of a hybrid asymmetric multilevel inverter for competitive medium-voltage industrial drives," IEEE Trans. Industry Applications," vol. 41, n², pp. 655-664, March-April 2005.

[9] P.C. Loh et al., "Modular hysteresis current control of hybrid multilevel inverters," IEE Proc. Electric Power Applications, vol. 152, n²1, pp. 1 8 , January 2005

[10] I. Boldea, "Control issues in adjustable speed drives, IEEE Industrial Electronics Magazine," vol. 2, n³, pp. 32-50, September 2008.

[11] G. Buja et al., "Steady-state performance degradation of a DTC IM drive under parameter and transduction errors," IEEE Trans. Industrial Electronics, vol. 55, n4, pp. 1749-1760, April 2008.

[12] G.S. Buja et al., "Direct torque control of PWM inverter-fed AC motors - A survey, IEEE Trans. Industrial Electronics," vol. 51, n 4 , pp. 744757, August 2004.

[13] D. Casadei et al., "FOC and DTC: two viable schemes for induction motors torque control," IEEE Trans. Power Electronics, vol. 17, n5, pp. 779-787, September 2002.

[14] M.E.H. Benbouzid et al., "A loss-minimization DTC scheme for EV induction motors," IEEE Trans. Vehicular Technology, vol. 56, $\mathrm{n}^{\circ} 1$, pp. 81-88, January 2007.

[15] M. Carpita et al., "Multilevel converter for traction applications: Smallscale prototype tests results," IEEE Trans. Industrial Electronics, vol. 55, n ${ }^{\circ}$, pp. 2203-2212, May 2008

[16] S. Lu et al., "A unique ultracapacitor direct integration scheme in multilevel motor drives for large vehicle propulsion," IEEE Trans. Vehicular Technology, vol. 56, n4, Part 1, pp. 1506-1515, July 2007.

[17] M. Manjrekar et al., "A hybrid multilevel inverter topology for drive application", in Proceedings of the IEEE APEC'98, Anaheim (USA) pp. 523-529, February 1998.

[18] A. Rufer et al., "Asymmetric multilevel converter for high resolution voltage phasor generation", in Proceedings of the EPE 99, Lausanne (Switzerland), September1999.

[19] X. del Toro Garcia et al., "Direct torque control of induction motors utilizing three-level voltage source inverters," IEEE Trans. Industrial Electronics, vol. 55, n², pp. 965-958, February 2008

[20] J. Rodriguez et al., "Direct torque control with imposed switching frequency in an 11-level cascaded inverter," IEEE Trans. Industrial Electronics, vol. 51, n4, pp. 827-833, August 2008.

[21] S. Kouro et al., "High-performance torque and flux control for multilevel inverter fed induction motors," IEEE Trans. Power Electronics, vol. 22, n6, pp. 2116-2123, November 2007. 